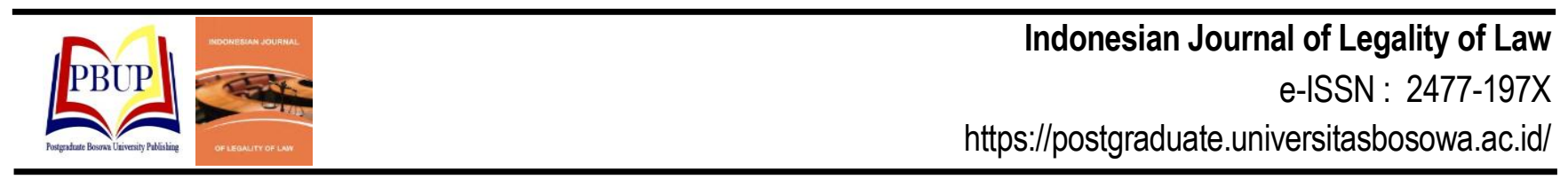

\title{
PENERAPAN SANKSI TERHADAP TINDAK PIDANA PEMALSUAN SURAT TANAH RINCI DI WILAYAH HUKUM POLRES MAROS
}

\author{
The Implementation of Sanctions for Forgery Crimes of Detailed Land Certificates in the Territory of \\ Maros Resort Police
}

\author{
Jufri Natsir ${ }^{1}$, Ruslan Renggong ${ }^{1}$, Baso Madiong ${ }^{1}$ \\ ${ }^{1}$ Program Studi Ilmu Hukum Program Pascasarjana Universitas Bosowa \\ Email: jurfrinatsir@gmail.com
}

Diterima: 01 April 2020/Disetujui: 05 Juni 2020

\begin{abstract}
ABSTRAK
Tujuan penelitian ini adalah untuk mengetahui penerapan hukum dan pertimbangan hakim dalam tindak pidana pemalsuan surat tanah rinci di wilayah Maros. penelitian menggunakan penelitian hukum empiris. Sumber data dari data primer dan sekunder. Kemudian data diolah dan disusun melalui tahap pengeditan, klasifikasi, verifikasi, analisis, dan kesimpulan. Verivikasi data menggunakan dua macam triangulasi, yaitu trianggulasi sumber dan triangulasi teori. Penerapan ketentuan pidana terhadap perkara yang terjadi di Maros hakim membebaskan terdakwa oleh karena hakim menilai perbuatan yang telah dilakukan terdakwa dianggap bukan tindakan pidana tetapi merupakan perkara pedata berdasarkan hasil dan fakta persidangan.
\end{abstract}

Kata Kunci: Sanksi, Tindak Pidana, Pemalsuan, Surat Tanah Rinci

\begin{abstract}
The purpose of this study was to determine the implementation of the law and the consideration of judges in the falsification of detailed land certificates in the Maros region. This research uses empirical legal research. Data sources are from primary and secondary data. Then the data is analysed and arranged through the stages of editing, classification, verification, analysis, and conclusions. Data verification uses two types of triangulation, namely source triangulation and theory triangulation. The implementation of criminal provisions against cases that occurred in Maros, the judge acquitted the defendant because the judge considered the actions carried out by the defendant were considered not a criminal act but constituted a court case based on the results and facts of the trial.
\end{abstract}

Keywords: Sanctions, Crime, Forgery, Detailed Land Certificates

\section{PENDAhuluan}

Indonesia merupakan suatu negara yang tatanan kehidupan dan perekonomian dominan agraris, di dalam memberikan rasa adil dan makmur kepada masyarakat maka pengaturan atas tanah yang merupakan sumber daya alam ditempatkan sangat penting untuk kelangsungan hidup. Tanah dijadikan tempat manusia hidup, tumbuh dan berkembang. Tanah sebagai sumber segala kepentingan hidup dan tanah juga menjadi komoditas untuk dikuasai dan dimiliki. Dalam memenuhi kebutuhan atas tanah bagi masyarakat, pemerintah menjalankan kebijakannya berlandaskan Pasal 33 ayat (3) UUD 1945, dan diperjelas dalam UUPA Pasal 1 ayat (2).

Perebutan atas tanah sering terjadi yang menimbulkan tindak pidana. Hal ini disebabkan oleh berbagai aspek, yaitu sosial, lingkungan, dan ekonomi yang mengakibatkan tindakan kriminal semakin beragam dengan model dan modus yang semakin canggih.
Pengaturan tindak pidana dalam KUHP, khusus untuk pemalsuan tertuang dalam BAB XII Buku II KUHP, dan pemalsuan surat terdapat di Pasal 263 KUHPidana s/d pasal 276 KUHPidana. Pelanggar pasal ini biasanya sering terjadi dalam perkara membuat surat palsu termasuk didalamnya membuat keterangan yang tidak benar atau menyuruh orang memasukan keterangan yang tidak benar.

Tindak pidana atau perbuatan pidana adalah perbuatan yang dilarang oleh suatu aturan hukum larangan mana disertai ancaman (sanksi) yang berupa pidana tertentu, bagi barang siapa yang melanggar larangan tersebut (Moeljatno 2002: 54). Menurut Moeljatno, bahwa tindak pidana adalah perbuatan yang dilarang dan diancam dengan pidana, terhadap barang siapa yang melanggar tersebut. Perbuatan itu harus pula dirasakan oleh masyarakat sebagai suatu hambatan tata pergaulan yang dicita-citakan oleh masyarakat.

Perbuatan pemalsuan merupakan suatu jenis pelanggaran terhadap kebenaran dan keterpercayaan, dengan tujuan memperoleh keuntungan bagi diri sendiri 
atau orang lain. Suatu pergaulan hidup yang teratur di dalam masyarakat yang maju teratur tidak dapat berlangsung tanpa adanya jaminan kebenaran atas beberapa bukti surat dan dokumen-dokumen lainnya. Karenanya perbuatan pemalsuan dapat merupakan ancaman bagi kelangsungan hidup dari masyarakat tersebut

Adami Chazawi (2001) mengemukakan bahwa pemalsuan surat adalah berupa kejahatan yang di dalam mengandung unsur keadaan ketidak benaran atau palsu atas sesuatu (objek), yang sesuatunya itu tampak dari luar seolah-olah benar adanya padahal sesungguhnya bertentangan dengan yang sebenarnya.

Soenarto Soerodibro (1994: 154), mengemukakan bahwa, barangsiapa di bawah suatu tulisan mebubuhkan tanda tangan 14 orang lain sekalipun atas perintah dan persetujuan orang tersebut telah memalsukan tulisan itu. Perbedaan prinsip antara perbuatan membuat surat palsu dan memalsu surat, adalah bahwa membuat surat/ membuat palsu surat, sebelum perbuatan dilakukan, belum ada surat, kemudian dibuat suatu surat yang isinya sebagian atau seluruhnya adalah bertentangan dengan kebenaran atau palsu. Seluruh tulisan dalam surat itu dihasilkan oleh perbuatan membuat surat palsu. Surat yang demikian disebut dengan surat palsu atau surat tidak asli. Unsur-unsur Pemalsuan Surat Pemalsuan surat diatur dalam Bab XII buku II KUHP, dari Pasal 263 sampai dengan Pasal 276 KUHP, yang dapat dibedakan menjadi 7 macam kejahatan pemalsuan surat, yakni:

Tujuan dari penelitian ini adalah menjelaskan penerapan hukum dan pertimbangan Hakim dalam mengadili perkara pemalsuan surat tanah rinci di wilayah Maros.

\section{METODE}

Lokasi penelitian dilaksanakan di Kabupaten Maros. Jenis penelitian adalah penelitian hukum empiris. Data bersumber dari hasil wawancara (primer) dan dari kajian pustaka (sekunder). Pengolahan dan analisis data melalui tahapan pengeditan data, klasifikasi data, verifikasi data, analisis data, dan Kesimpulan

Teknik mengabsahkan data memakai teknik triangulasi sumber dan triangulasi teori. Penggunaan triangulasi sumber dengan cara membandingkan apa yang dikatakan dengan apa yang dipraktikan, membandingkan informasi dari para informan, membandingkan hasil wawancara dengan data sekunder. Sedangkan triangulasi teori dilakukan dengan mengecek data dan dibandingkan dengan teori-teori yang sudah ada.

\section{HASIL DAN PEMBAHASAN}

Penerapan pidana tidak terlepas dari teori pertanggungjawaban pidana. Dalam hal ini ada dua pandangan, yaitu ministis dan dualistis. Pandangan ministis menilai unsur pertanggungjawaban pidana mencakup perbuatan dan pembuat. Perbuatan atau unsur objektif, dan unsur pembuat disebut sebagai unsur subjektif. Pandangan ministis menyimpulkan jika terjadi delik, maka si pelakunya bisa kena pidana, jadi aliran monistis berpendapat bahwa pertanggungjawaban pidana sama dengan syarat-syarat penjatuhan pidana. Sementara dualistis memisahkan antara unsur perbuatan dengan pembuat. Pandangan ini menyatakan bahwa unsur perbuatan menyangkut delik, sementara dalam hal pertanggungjawaban pidana terdapat unsur pembuat. Maka dari itu, yang paling relevan dengan kajian ini adalah aliran dualistik dimana pertanggungjawaban pidana dipisahkan antara unsur objektif (delik/tindak pidana) dengan unsur subjektif (pertanggungjawaban). Sehingga KUHAP memberi kemudahan bagi hakim dalam memutuskan perkara. Untuk memidanakan seseorang haruslah memenuhi ketentuan pemidanaan, jika tidak memenuhi syarat, maka seseorang tidak dapat dimintakan pertanggungjawaban pidana.

Mengamati permasalahan yang terjadi pada kedua perkara sampel penelitian yang diadili di Pengadilan Negeri Maros yang pada awalnya masing mengklaim sama-sama mengaku sebagai pemilik tanah yang sah.

Bila kita merujuk pada aturan dalam pasal $28 \mathrm{H}$ UUD 1945 disebutkan bahwa setiap orang mempunyai hak atas hak milik dan tidak boleh diambil alih secara sewenang-wenang oleh siapapun. Negara harus menjamin hak-haknya warganya termasuk didalamnya adalah hak milik tanah. Dalam UU No. 5 Tahun 1960 pasa 2 ditentukan bahwa bumi air dan segala isinya dikuasai oleh negara. Dengan demikian negara berwenang untuk mengatur dan menyelenggarakan peruntukan atas kekayaan negara, mengatur antara orang dengan bumi, mengatur dan menentukan hubungan antara orang dan perbuatannya.

UUPA diatur atas hak-hak pengusaan atas tanah termasuk di dalamnya hak perorangan yang memiliki aspek perdata. Hak atas tanah terdiri dari hak milik; hak guna usaha; hak guna bangunan; hak pakai; hak sewa; hak membuka tanah; hak memungut hasil hutan, dan hak pengelolaan. Terhadap hak atas tanah milik negara juga harus memberikan jaminan kepastian hukum dalam hal ini pemerintah melakukan pendaftran tanah agar terlindungi secara hukum. Produk dari pendaftaran tanah adalah berupa sertifikat.

Sertifikat berfungsi sebagai alat untuk pemegangnya untuk mendapatkan kepastian tentang lokasi, batas, serta luas tanah, sehingga dapat menjadi perlindungan terhadap gangguan pihak lain agar tidak menjadi bahan sengketa dengan yang lain. Untuk itu setiap orang wajib menghormatinya karena dijamin oleh konstitusi. Untuk itu, pemanfaatan tanah yang bukan miliknya, semestinya dan harus dilakukan sesuai aturan dan tidak boleh dikuasai secara sewenang-wenang.

Meskipun telah diakui dalam UUPA, mengenai sertifikat tanah ternyata kepastian pemiliknya belum dijamin secara utuh karena masih terdapat peluang bagi pihak lain untuk menggugat, baik ke peradilan umum atau menggugat Kepala BPN ke PTUN. Peluang gugatan tersebut adalah ternyata sertifikat mempunyai sisi keperdataan dan sisi yang merupakan bentuk keputusan yang bersifat penetapan (beschiking) oleh Kepala Kantor Pertanah.

Mengenai rincik, sebelum adanya UUPA, rinci mendapat pengakuan atas kepemilikan hak atas tanah, namun ketika UUPA terbit, hanya sertifikat yang mendapat pengakuan hak milik atas tanah. Namun demikian, dalam keyakinan masyarakat pada umumnya bahwa rincik masih diakui sebagai tanda bukti hak atas tanah. Masyarakat tifak ambil pusing apakah rincik itu produk sebelum UUPA atau sesudahnya yang pasti dalam pemahaman mayarakat kalau adan rincik berarti pemiliknya sudah merasa aman.

Sistem stelsel negatif adalah sistem yang diipakai dalam pendaftaran tanah, artinya sertifikat hak atas tanah menjadi 
bukan satu-satunya hak yang mutlak, karena bukan merupakan hak mutlak maka semua orang berhak mengajukan keberatan bagi mereka yang merasa berhak. Namun demikian, pengadilan dalam memutuskan harus mempertimbangkan rincik jika orang yang memegang sertifikat ataupun bagi mereka yang mengadakan gugatan terhadap keberadaan sertifikat tersebut. Namun bukti rincik saja tidak cukup karena harus diikuti bukti lain yang menunjukkan kepemilikan atau mempunyai hubungan hukum antara tanah yang dipersoalkan dengan si pemilik atau si penggugat tersebut. Rincik masih harus diuji secara materil, sekalipun orang yang mengetahui keberadaan rincik secara detail sudah jarang ditemukan.

Panitia ajudikasi harus lebih teliti dalam menerima pendaftaran tanah. Hal ini tentunya sesuai dengan PP No. 24 Tahun 1997 pasal 24 dan 25 mengenai pendaftaran tanah. Pendaftar harus bisa membuktikan hak lama dengan disertai alat bukti tertulis disertai saksi atau setidaknya ada pernyataan dari si pemohon yang setelah ditelusuri secara yuridis. Dengan alat bukti yang ada dan dibuatkan berita acara pengesahan hak atas tanah yang sdh memenuhi syarat berdasarkan data yuridisnya dan lengkap barulah dimasukan dalam buku tanah untuk diterbitkan sertifikatnya. Yang dimasuk dengan data yuridis adalah keterangan mengenai status hukum tanah yang didaftarkan, pemegang hak dan hak pihak lain. Tentang keterangan letak, batas, dan luasan termsuk keterangan mengenai bangunan diatasnya bagi tanah yang akan didaftar merupakan data fisik.

Intinya, berdasarkan uraian sebelumnya, rincik saja tdak cukup kuat untuk membuktikan hak atas tanah, hal ini dikarenakan kepemilikan rincik harus diserta data fiksi dan yuridis, dan sekurang-kurangnya harus dibuktikan dengan pengusaan atas tanah tersebut minimal selama 20 tahun secara terus-menerus, selain itu diperlukan kesaksian dari orang yang dianggap mengetahui sejarah tanah tersebut, dan tanah tersebut tidak pernah ada orang yang mempermasalahkannya baik secara hukum formal maupun secara adat.

Hal ini sesuai dengan apa yang dikatakan hakim pengadilan negeri maros Muhammad Iqbal yang mengatakan bahwa:

"ya....sekalipun yang berperkara memagang surat berupa rincik, akan tetapi itu tidak cukup karena surat rincik harus disertai dengan bukti fisik dan bukti yurudis yang lainnya...dan dalam aturan kan dijelaskan bahwa pengusaan atas tanah secara fisik oleh yang bersangkutan atau pemgenag rincik penguasaan tanah tersebut harus secara berturut-turut secara terus menerus selama 20 tahun atau lebih baru rincik bisa dijadikan pegangan tentunya setelah dilakukan pemeriksaan kebeeradaannya" (Wawancara, 8 Februari 2020).

Berdasarkan hasil wawancara tersebut membuktikan bahwa bukti rincik saja tidak cukup untuk dijadikan satusatunya alat bukti kepemilikan tanah, namun bukti tersebut harus diikuti dengan bukti-bukti pendukung. Namun jika tanah tersebut belum ada sertifikatnya, maka rincik dapat dijadikan bukti kepemilikan awal untuk proses pendaftaran tanah sepanjang bukti tersebut disertai dengan bukuti-bukti pendukung yang menguatkan kepemilikan terhadap tanah tersebut.

Selanjutnya, dalam perkara pertimbangan hakim dalam menjatuhkan sanksi untuk berat atau ringann sanksi tersebut merupakan kebebasan hakim yang dijamin oleh undangundang. Kebebasan tersebut bersifat mutlak dan tidak ada yang bisa campuri dari manapun. Kewenangan ini diberikan sebagai jaminan dalam memutuskan perkara secara objektif, sekalipun hakim harus mempedomani aturan, karena dalam aturan ada batasan maksimum dan minimum agar rasa keadilan itu dapat dirasakan baik oleh terdakwa atupun masyarakat yang ikut berperkara. Hakim juga dalam memutuskan perkara harus memperhatikan alat bukti lain yang terungkap dalam proses persidangan, jika alat bukti yang dihadirkan mempunyai kerekaitan dengan perkara yang disidangkan berarti dapat membuktikan terdakwa bersalah, dan jika sebaliknya, alat bukti yang dihadirkan tidak ada hubungannya dengan perkara yang sidangkan maka ini yang biasanya menimbulkan hakim menjadi tidak yakin dengan kebenaran pembuktian terdakwa.

Dalam putusan pengadilan atas perkara Nomor 24/Pid.B/2016/PN.Maros terdakwa oleh penuntut umum didakwa dengan dakwaan Pasal 167 ayat (1). Dakwaan tersebut dinyatakan bahwa perbuatan telah terbukti, namun perbuatan tersebut dinyatakan bukanlah merupakan suatu tindak pidana (onslag van recht vervolging), Putusan Majelis Hakim menganggap bahwa sudah sesuai dengan fakta-fakta persidangan, dan unsur onslag van recht vervolging yang namun berdasarkan fakta persidangan dan bukti-bukti yang diperiksa hakim menganggap ini bukan kasus pidana sehingga hakim membesakan terdakwa dari segala tuntutan.

\section{KESIMPULAN}

Kesimpulan penelitian ini bahwa penerapan hukum terhadap perkara yang disidangkan di PN Maros dengan nomor perkara 24/Pid.B/PN.Maros dan nomor 160/PID.B/2017/PN.Mrs terdapat kesalahan penerapan pasal yang didakwakan oleh penuntut umum, karena berdasarkan fakta dan bukti yang diajukan dipersidangan hakim menyatakan bahwa perbuatan tersebut bukan perbuata pidana. Dalam proses persidangan, pertimbangan dan keyakinan hakim menjadi hal yang sangat penting untuk menentukan bersalah atau tidak, berat atu ringan hukum yang akan dijatuhkan.

\section{DAFTAR PUSTAKA}

Adami Chazawi. 2001. Kejahatan Terhadap Pemalsuan. PT. RajaGrafindo Persada. Jakarta.

Adami Chazawi. 2005. Pelajaran Hukum Pidana 1. PT. RajaGrafindo Persada. Jakarta.

Kajadi. M, 1981, Kitab UndangUndang Hukum Acara Pidana Lengkap Disertai Lampiran-Lampiran Yang Berkaitan Dengan Acara Pidana Di Indonesia, Politela, Bogor.

Kitab Undang-Undang Hukum Pidana (KUHP), 2010. Cetakan Kedua. PT. Buku Kita. Jakarta

Masriari, Tiena, Yesmil, 2009, Sistem Peradilan Pidana, Widya Padjajaran, Bandung.

Moeljatno, 2002, Asas-Asas Hukum Pidana, PT. Rineka Cipta, Jakarta.

P.A.F Lamintang. 2009. Delik-Delik Khusus: Kejahatan Membahayakan Kepercayaan Umum Terhadap Surat, Alat Pembayaran, Alat Bukti dan Peradilan. Sinar Grafika. Jakarta.

Poerwadarminta, W.J.S, 2003, Kamus Umum Bahasa Indonesia Edisi Ketiga, PN Balai Pustaka, Jakarta.

R. Soesilo. 1996. Kitab Undang-Undang Hukum Pidana (serta komentarkomentar Pasal demi Pasal). Politea. Bogor.

Soerodibroto Soenarto, 1994. KUHP dan KUHAP. Raja Grafindo Persada. Jakarta. 
Topo Santoso, 2001. Kriminologi. PT. Raja Grafindo Persada. Jakarta.

Undang-Undang Dasar Negara Republik Indonesia 1945, Penjelasan Umum.

Undang-Undang Nomor 5 Tahun 1960 Tentang UndangUndang Pokok Agraria 